\begin{tabular}{r|l|l|l}
$\begin{array}{r}\text { Case Reports in } \\
\text { Gastruanterology }\end{array}$ & $\begin{array}{l}\text { Case Rep Gastroenterol 2010;4:452-456 } \\
\text { DOl: 10.1159/000321573 }\end{array}$ & $\begin{array}{l}\text { Published online: } \\
\text { October 18, 2010 }\end{array}$ & $\begin{array}{l}\text { O 2010 S. Karger AG, Basel } \\
\text { ISSN 1662-0631 } \\
\text { www.karger.com/crg }\end{array}$ \\
\hline
\end{tabular}

\title{
Solitary Peutz-Jeghers Polyp in a Paediatric Patient
}

\author{
Giuseppe Retrosia Lorenzo Nanni $^{a} \quad$ Fabio Maria Vecchio ${ }^{b}$ \\ Carlo Manzoni $^{\mathrm{a}}$ Raffaella Canali ${ }^{\mathrm{a}}$ Gaia Busato ${ }^{\mathrm{a}}$ \\ Claudio Pintus $^{\mathrm{a}}$
}

a Department of Paediatrics, Division of Paediatric Surgery, and bepartment of Human Pathology, Università Cattolica del Sacro Cuore, Policlinico 'A. Gemelli', Rome, Italy

\section{Key Words}

Peutz-Jeghers syndrome · Solitary Peutz-Jeghers polyp · STK11/LKB1 gene

\begin{abstract}
Hamartomatous polyps of Peutz-Jeghers are mostly found in patients affected by Peutz-Jeghers syndrome (PJS), but they can be rarely encountered in the general population. It is unclear whether a solitary Peutz-Jeghers polyp (PJP) is an incomplete form of PJS or a separate entity. We report a case of solitary PJP in a paediatric patient in whom the other features of PJS were absent. The patient underwent laparotomy due to small bowel intussusception secondary to an ileac polyp. Histological examination showed the characteristic features of PJP, but the patient did not fulfill the WHO criteria for PJS diagnosis (negative family history for PJS and absence of mucocutaneous pigmentation); moreover analysis of the STK11/LKB1 gene did not reveal any genomic abnormality. The clinical and investigative findings in our case suggest that the solitary PJP can be considered a different clinical entity from PJS.
\end{abstract}

\section{Introduction}

Peutz-Jeghers syndrome (PJS) is an autosomal dominant disease, with an incidence of $1 / 150,000$, characterised by hamartomatous polyps of the gastrointestinal tract, melanin deposits in the lips, buccal mucosa, perioral area and/or facial skin, and family history of PJS [1]. It is linked to a variety of intestinal and extraintestinal neoplasms with a cumulative lifetime risk for cancer of $93 \%, 18$ times greater than expected in the general population [2]. According to the WHO criteria the diagnosis of PJS can be made when the presence of mucocutaneous pigmentation, bowel hamartomatous polyps and family history of PJS are found simultaneously [3]. The polyps in patients with PJS have a distinct histological appearance with a characteristic arborising pattern of smooth muscle proliferation [1]. PJS arises in the second and third decade of life and presenting 


\begin{tabular}{r|l|l|l}
$\begin{array}{r}\text { Case Reports in } \\
\text { Gastruenterology }\end{array}$ & $\begin{array}{l}\text { Case Rep Gastroenterol 2010;4:452-456 } \\
\text { DOI: 10.1159/000321573 }\end{array}$ & $\begin{array}{l}\text { Published online: } \\
\text { October 18, 2010 }\end{array}$ & $\begin{array}{l}\text { O 2010 S. Karger AG, Basel } \\
\text { ISSN 1662-0631 } \\
\text { www.karger.com/crg }\end{array}$ \\
\hline
\end{tabular}

symptoms include abdominal pain, rectal bleeding, anemia, small intestine intussusception, bowel obstruction, and prolapse of rectal polyps; solitary Peutz-Jeghers polyps (PJPs) can rarely occur in patients without other features of PJS $[1,3,4]$.

Although several cases of solitary PJP have been reported in the literature [3-12], it is still unclear whether solitary PJP represents an incomplete form of PJS or a different entity $[2,6]$. We report the case of a paediatric patient with a solitary PJP in whom the other features of PJS were lacking.

\section{Case Report}

A 13-year-old girl was admitted to the emergency department with colicky abdominal pain lasting $12 \mathrm{~h}$. At physical examination her abdomen was diffusely tender, laboratory tests were normal and blood cells count showed $14,000 \mathrm{WBC} / \mathrm{mm}^{3}$. Abdominal ultrasonography on admission was normal. Due to worsening of her abdominal pain and clinical condition during the ensuing hours, an abdominal CT scan was performed, which revealed a small bowel intussusception. At laparotomy a small bowel intussusception was confirmed at about $1 \mathrm{~m}$ from the ileocecal valve (fig. 1). After resolution of the intussusception an intraluminal bowel polyp was palpated and therefore a short length of intestine (about $3 \mathrm{~cm}$ ) was resected (ig. 2 ) and an intestinal anastomosis was performed. The postoperative course was unremarkable.

Histological examination of the polyp showed proliferation of the mucosal epithelium with a central connective stroma and bundles of smooth muscle tissue (fig. 3). These features were consistent with the diagnosis of PJP. Physical examination of the patient showed no mucocutaneous pigmentation, and family history was negative for PJS, including that of gastrointestinal cancers and polyposis. The following screening exams (a total colonoscopy, a gastroesophageal endoscopy and a capsule endoscopy) did not show any additional polyps. Genetic analysis was performed; with informed consent we looked for the mutation of the STK11/LKB1 gene that has been found to be linked with PJS [1]. No mutation of STK11/LKB1 was detected.

\section{Discussion}

PJS is an autosomal dominant disease characterised by hamartomatous gastrointestinal polyps and melanin deposits. It is associated with a high rate of intestinal and extraintestinal neoplasms and some authors therefore suggest an age range-specific surveillance follow-up [1].

Solitary PJPs are a rare, usually incidental finding. Microscopically, extensive smooth muscle proliferation, with an elongated, arborised pattern of polyp formation, can be seen (fig. 3). This characteristic microscopic appearance of PJS polyps enables experienced gastrointestinal pathologists to confirm the clinical diagnosis [1] and to distinguish these kinds of polyps from other types of hamartomatous polyps. Solitary PJPs are identical to those found in PJS patients, but the other phenotypic characteristics are lacking. Whenever a PJP is found, it is important to rule out the diagnosis of PJS on the basis of the WHO criteria: (1) three or more histologically confirmed PJPs; (2) any number of PJPs with a family history of PJS; (3) characteristic, prominent, mucocutaneus pigmentations with a family history of PJS; (4) any number of PJPs and characteristic, prominent, mucocutaneous pigmentation [3].

A colonoscopy and an upper gastrointestinal endoscopy should be performed. Nevertheless jejunum and ileum are the most frequently involved tracts in PJS, therefore investigation of the entire small bowel is necessary to rule out polyps. Double contrast 


\begin{tabular}{|c|c|c|c|}
\hline $\begin{array}{l}\text { Case Reports in } \\
\text { Gastuallerolony }\end{array}$ & $\begin{array}{l}\text { Case Rep Gastroenterol 2010;4:452-456 } \\
\text { DOI: } 10.1159 / 000321573\end{array}$ & $\begin{array}{l}\text { Published online: } \\
\text { October } 18,2010\end{array}$ & $\begin{array}{l}\text { @ } 2010 \text { S. Karger AG, Basel } \\
\text { ISSN 1662-0631 } \\
\text { www.karger.com/crg }\end{array}$ \\
\hline
\end{tabular}

gastrointestinal studies followed by MRI are considered the gold standard [13] to detect small bowel polyps; in our opinion capsule endoscopy is superior to both methods because it avoids exposure to X-rays and the need for general anaesthesia, which is necessary to perform an MRI in the paediatric patient. Capsule endoscopy is a very sensitive procedure as it allows the detection of polyps $<1.5 \mathrm{~cm}$; moreover it can be very useful in the follow-up of PJS patients.

STK11/LKB1 encodes a serine-threonine kinase which is considered a tumour suppressor gene that acts as an early gatekeeper regulating the development of PJPs. A mutation on the short arm of chromosome 19 (19p13.3) of STK11/LKB1 is documented in up to $70-80 \%$ of PJS cases and it is responsible for the phenotypic expression $[1,7]$. Although the classic clinical and histopathologic features of PJS might sometimes obviate the need for genetic testing, analysis of germline STK11/LKB1 mutations may be helpful when the clinical features are subtle or when the histological diagnosis is in question [1]; we therefore recommend performing genetic analysis in any case of PJP which does not fulfill the WHO criteria for the diagnosis of PJS. In our case we performed a genetic analysis that did not detect any STK11/LKB1 mutation linked with PJS.

The patients with solitary PJP described in the above reports were observed mostly in the fourth decade of life, whereas PJS patients present more often in the second or third decade of life [1]. To our knowledge the youngest patients in the English language literature before our report were a 22 -year-old woman and two 19-year-old men $[3,5,8]$.

In conclusion, our case is the youngest patient reported with a diagnosis of solitary PJP, and further genetic testing in the present case supports the theory that solitary PJP is a different clinical entity from PJS. It is unknown whether patients with PJP have a lifelong risk of cancer similar to the general population or whether they need a specific high-risk screening $[2,4]$; we suspect that patients with solitary PJP probably do not have a higher risk of cancer than the general population, but this hypothesis needs to be confirmed by further studies.

\section{Acknowledgement}

We are grateful to Dr. Mark Bishay for his helpful comments on the manuscript. 


\begin{tabular}{l|l|l|l}
$\begin{array}{r}\text { Case Reports in } \\
\text { Gastroenterology }\end{array}$ & $\begin{array}{l}\text { Case Rep Gastroenterol 2010;4:452-456 } \\
\text { DOl: 10.1159/000321573 }\end{array}$ & $\begin{array}{l}\text { Published online: } \\
\text { October 18, 2010 }\end{array}$ & $\begin{array}{l}\text { O 2010 S. Karger AG, Basel } \\
\text { ISSN 162--0631 } \\
\text { www.karger.com/crg }\end{array}$ \\
\hline
\end{tabular}

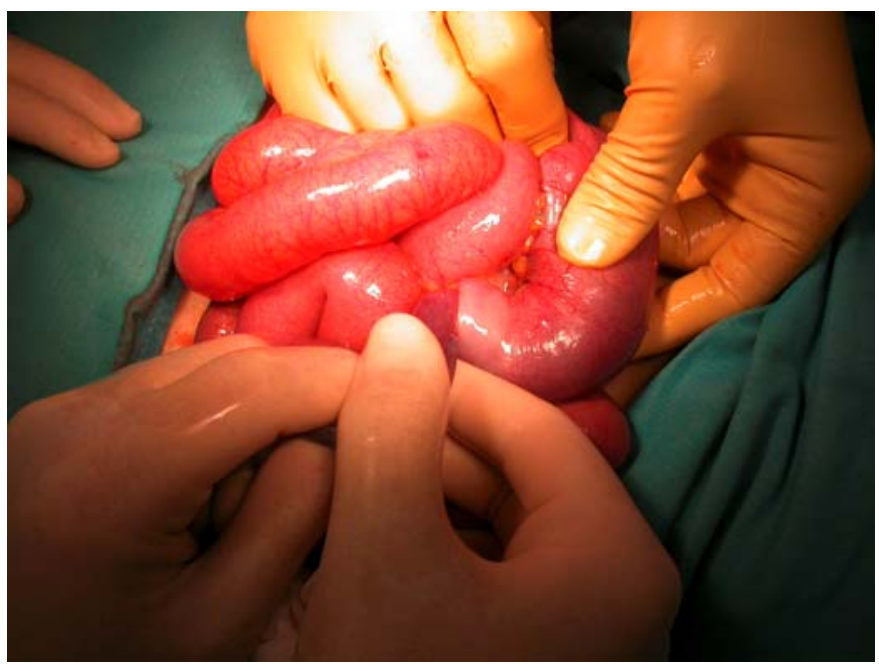

Fig. 1. Manual resolution of bowel intussusception during the surgical procedure.

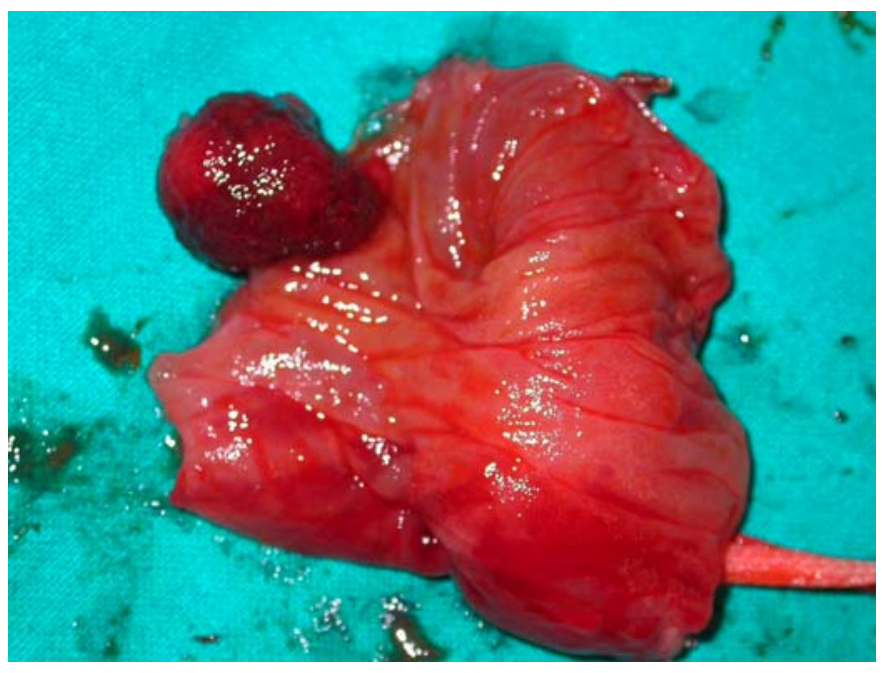

Fig. 2. Intraluminal polyp after surgical resection. 


\begin{tabular}{r|l|l|l}
$\begin{array}{r}\text { Case Reports in } \\
\text { Gastruanteriology }\end{array}$ & $\begin{array}{l}\text { Case Rep Gastroenterol 2010;4:452-456 } \\
\text { DOI: 10.1159/000321573 }\end{array}$ & $\begin{array}{l}\text { Published online: } \\
\text { October 18, 2010 }\end{array}$ & $\begin{array}{l}\text { O 2010 S. Karger AG, Basel } \\
\text { ISSN 1662-0631 } \\
\text { www.karger.com/crg }\end{array}$ \\
\hline
\end{tabular}

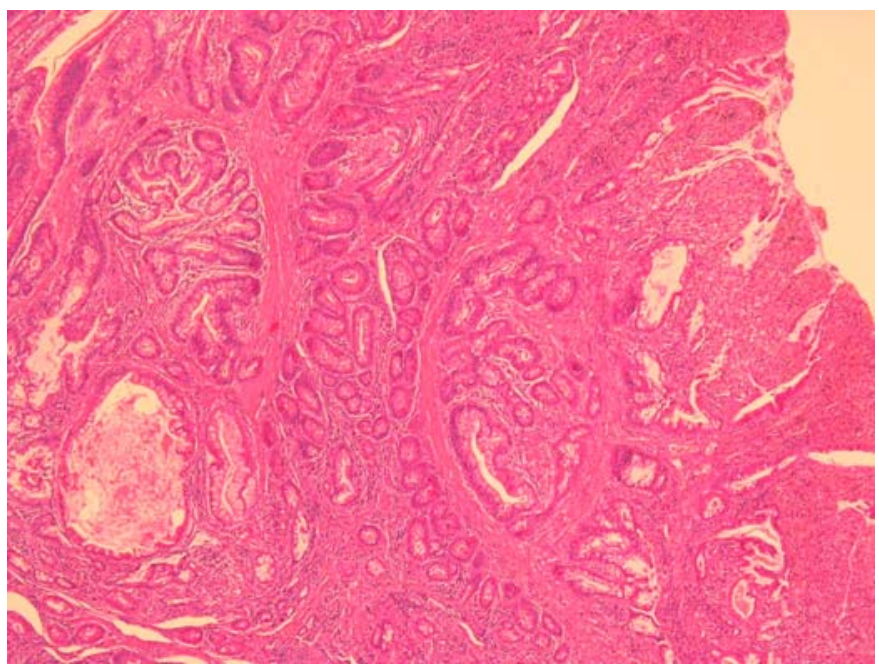

Fig. 3. Hyperplastic polyp epithelium is separated by branching bundles of smooth muscle.

\section{References}

1 Zbuk KM, Eng C: Hamartomatous polyposis syndromes. Nat Clin Pract Gastroenterol Hepatol 2007;4: 492-502.

2 Burkart AL, Sheridan T, Lewin M, et al: Do sporadic Peutz-Jeghers polyps exist? Experience of a large teaching hospital. Am J Surg Pathol 2007;31:1209-1214.

3 Ter Borg PP, Westenend PP, Hesp FW, et al: A solitary Peutz-Jeghers type polyp in the jejunum of a 19 year-old male. Cases J 2008;1:68.

4 Oncel M, Remzi FH, Church JM, et al: Course and follow-up of solitary Peutz-Jeghers polyps: a case series. Int J Colorectal Dis 2003;18:33-35.

5 Kitaoka F, Shiogama T, Mizutani A, et al: A solitary Peutz-Jeghers-type hamartomatous polyp in the duodenum. A case report including results of mutation analysis. Digestion 2004;69:79-82.

-6 Acea Nebril B, Taboada Filgueira L, Parajó Calvo A, et al: Solitary hamartomatous duodenal polyp; a different entity: report of a case and review of the literature. Surg Today 1993;23:1074-1077.

7 Fraser JD, Briggs SE, St Peter SD, et al: Intussusception in the adult: an unsuspected case of Peutz-Jeghers syndrome with review of the literature. Fam Cancer 2009;8:95-101.

-8 Jaremko JL, Rawat B: Colo-colonic intussusception caused by a solitary Peutz-Jeghers polyp. Br J Radiol 2005;78:1047-1049.

-9 Suzuki S, Hirasaki S, Ikeda F, et al: Three cases of solitary Peutz-Jeghers-type hamartomatous polyp in the duodenum. World J Gastroenterol 2008;14:944-947.

10 Itaba S, Iboshi Y, Nakamura K, et al: Education and imaging. Gastrointestinal: Solitary Peutz-Jeghers-type hamartoma of the colon. J Gastroenterol Hepatol 2009;24:498.

11 Kantarcioglu M, Kilciler G, Turan I, et al: Solitary Peutz-Jeghers-type hamartomatous polyp as a cause of recurrent acute pancreatitis. Endoscopy 2009;41(suppl 2):E117-E118.

12 Sakadamis AK, Ballas KD, Fardellas JG, et al: A solitary gastric Peutz-Jeghers type polyp: report of a case. Surg Today 2001;31:517-520.

13 Kurugoglu S, Aksoy H, Kantarci F, et al: Radiological work-up in Peutz-Jeghers syndrome. Pediatr Radiol 2003;33:766-771. 